\title{
Public and Private Sector Relations for Economic Growth: Evidence from Uzbekistan
}

\author{
Javlonbek Kurbonov \\ Department of Financial Management, Tashkent Financial Institute \\ 60 A, Amir Temur street, 100000, Tashkent, Uzbekistan
}

\begin{abstract}
In the era of globalized economic relations, public and private sector cooperates for creating a joint value and social impact in the well-being of socio-economic condition. Hence, public-private relations are not developed evenly and differentiate in coverage, quality and proximity due to factors, motives and interests of both parties. This article studies the global condition of public-private relations and compares the practices with Uzbekistan's experience.
\end{abstract}

Keywords: public and private sector relations, PPP, public procurement, Uzbekistan.

\section{Introduction}

Public and corporate sector partnership is recognized as an effective way of delivering value-for-money public infrastructure or services. It seeks to combine the advantages of competitive tendering and flexible negotiation, and to allocate risk on an agreed basis between the public sector and the private sector (Li et al., 2005). Being the main provider of large economic output in developing and transition economies, corporate sector holds the key position as an employer, supplier of public goods and services and taxpayer. From historical perspective, public and private sector relations were in a smaller extent, as it was seen as a contractual or a memorandum-driven agreement between public offices and private enterprises. As corporate relations developed and expanded the horizon, public and private relations grew and become the natural extension of mixed economic system by sharing the resources such as financing, labor, capital and management. In some economies, they exist as a transitional step between a public service and a privatized service. It is called corporatization, which purports to ease the adjustment from public-to-private transformations by gradually incorporating market-based decisions. The very practice is expanding in transition and developing economies, as government is transferring the supply of some public goods and services to private providers.

Hence, there is a confused view in public and private sector relations and privatization. Gerrard (2015) defined that a privatized business is one that was formerly owned by the public sector and is now owned by the private sector. By contrast, a public and private sector relations are a business relationship between the public and private sectors that is not patterned on either of these models. In letter definition, public and private sector relations combine the deployment of private sector capital and, sometimes, public sector capital to improve public services or the management of public sector assets. By focusing on public service outputs, they offer a more sophisticated and cost-effective approach to the management of risk by the public sector than is generally achieved by traditional input-based public sector procurement.

Public and private sector relations seek profit and often spread the costs of procuring an asset over time or cause the associated capital expenditure to affect private firms' rather than the public sector's balance sheets, as a key aim of them are the deployment of private sector capital.

\section{Literature Review}

Public and private sector relations are a comparatively new topic of research, as previous studies were conducted on fiscal importance of private sector as a taxpayer and an employer. Modern approaches to business and corporate relations required the scientific investigation of upgraded public can private sector linkages. Initial research on this topic was conducted by Spackman (2002), Valila (2005), Grimsey and Lewis (2005), Li, et al. (2005), Currie (2005), Jefferies (2006), Chung, Hensher and Rose (2010), Viegas (2010), Liu and Wilkinson (2010), Dūda (2010), Moszoro (2010). However, most of them assessed the importance of public anfd private sector relations from value for money side. On the other hand, Hall (2008) and Tang, et al. (2010) studied effect of public and private sector interactions in public procurement, but in investment and capital flows. Chen and Chiu (2010), Takashima, Yagi and Takamori (2010) and Jasiukevicius \& Vasiliauskaite (2012) examined the impact of public and private partnership on economic growth and found a positive effect. 


\section{Public and Private Sector Relations and Their Effect in Economic Growth: Global Overview and International Best Practices}

Over the last two decades private sector financing through public-private partnerships (PPP) has become increasingly popular as a way of procuring, renewing and maintaining public sector infrastructure in many sectors such as social infrastructure, transportation, public utilities, communications, government offices and others in which public services are provided (Jasiukevicius and Vasiliauskaite, 2013). PPPs are the main mode of public and private sector relations, which may fully reflect the features depending on the scope of relations in economies. Global debate on impact of public and private sector relations on economic growth is in very active phase, many policymakers and experts are offering several models, types and procedures of PPP in accordance with economic profile of the country. However, they agree that public and private sector relations support economic growth through following channels: (i) a potential to simplify procurement of capital, (ii) transfer of responsibility and risk to a single provider, (iii) operation of new facilities can be considered earlier in the process, (iv) long-term focus can be built into the project, (v) operational is given a higher priority in relation to the more short-term design and construction stages, (vi) focus on the overall package can ensure integration between, design, construction, finance and operation.

Figure 1. Impact of public and private relations on economic growth.

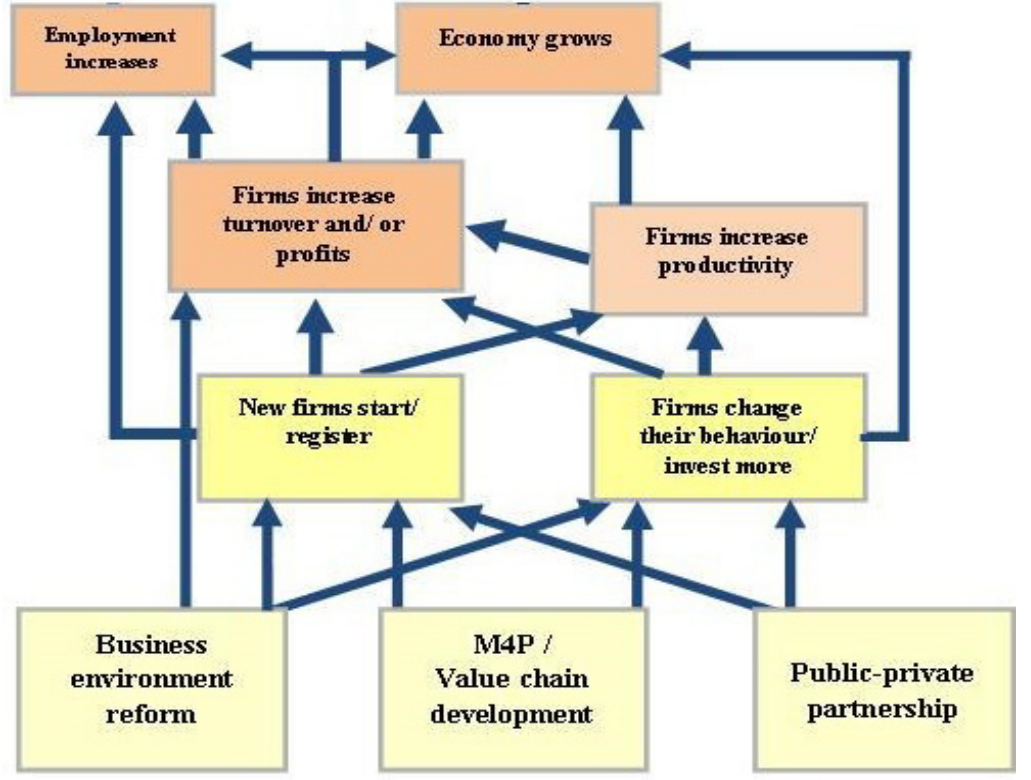

Source: Author's compilations

Coverage and scope of public and private sector relations differ in countries depending on the business sector, corporate relations and public finances. Therefore, they have diverse modes, procedures and orientations for private sector deployment in public relations. Governments can mobilize additional financial resources and gain access to valuable expertise by structuring projects as public-private partnerships. Successfully functioning schemes are of developed economies, in which private sector was fully formed and developed at equal extent in terms of funding and wealth. Many experts highly evaluates the functioning of the United Kingdom's Private Finance Initiative, which began in 1992 and manages the public investment projects in most of the key infrastructure areas. Australia and Ireland, while the United States has considerable experience with leasing. Finland, Germany, Greece, Italy, the Netherlands, Portugal and Spain are developing their public and private sector relations in public investment. Canada and Japan are actively expanding the private sector participation in road and infrastructure projects. Czech Republic, Hungary, and Poland, have embarked on PPPs due to the need for infrastructure investment on a large scale, and comparatively weaker fiscal positions. Deriving from the channels of impact and orientation of the government and private entity, several forms and modalities of public and private relation can implemented (Table 1). 
Table 1. Schemes and modalities in public and private sector relations

\begin{tabular}{|c|c|}
\hline Schemes & Modalities \\
\hline Build-own-operate (BOO) & \multirow{3}{*}{$\begin{array}{l}\text { The private sector designs, builds, owns, } \\
\text { develops, operates and manages an asset with } \\
\text { no obligation to transfer ownership to the } \\
\text { government. These are variants of design- } \\
\text { build-finance-operate (DBFO) schemes. }\end{array}$} \\
\hline Build-develop-operate (BDO) & \\
\hline Design-construct-manage-finance (DCMF) & \\
\hline Buy-build-operate (BBO) & \multirow{3}{*}{$\begin{array}{l}\text { The private sector buys or leases an existing } \\
\text { asset from the government, renovates, } \\
\text { modernizes, and/or expands it, and then } \\
\text { operates the asset, again with no obligation to } \\
\text { transfer ownership back to the government. }\end{array}$} \\
\hline Lease-develop-operate (LDO) & \\
\hline Wrap-around addition (WAA) & \\
\hline Build-operate-transfer (BOT) & \multirow{5}{*}{$\begin{array}{l}\text { The private sector designs and builds an } \\
\text { asset, operates it, and then transfers it to the } \\
\text { government when the operating contract } \\
\text { ends, or at some other prespecified time. The } \\
\text { private partner may subsequently rent or } \\
\text { lease the asset from the government. }\end{array}$} \\
\hline Build-own-operate-transfer (BOOT) & \\
\hline Build-rent-own-transfer (BROT) & \\
\hline Build-lease-operate-transfer (BLOT) & \\
\hline Build-transfer-operate (BTO) & \\
\hline
\end{tabular}

\section{Role of Public and Private Sector Linkages in Uzbekistan: Business Support for Growth}

Uzbekistan is a progressive economy with regular growth and consecutive reforms towards market economy. As a post Soviet economy, Uzbekistan has transforming the ownership structure and national output composition. Agricultural specialization of economy was diversified into several sectors and got rid of dependency of economy for agricultural output. Increasing volume of private sector output and spread of multiple forms of business entities lays the foundation for liberalization and access in domestic business atmosphere. Decentralization of public assets and their privatization increased added an impetus in domestic production and net output. Nowadays, public assets and private assets have equal status of importance in terms of supply and production of goods and services. Public and private sectors are driving the smooth provision of socio-economic stability. Therefore, it can be trustworthily said that public and private sector relations are in bridging phase.

Public and private sector relations gain the central importance in the supply of public goods and services, infrastructure and social outputs. Private entities can be reliable tool in delivery of key public services and infrastructure projects with high social importance. Public procurement and construction are main areas of private sector participation as a provider. Legal foundations of public private partnership in public procurement, construction, health and utility sectors have been strengthened by governmental actions, initiatives and frameworks. Consequently, private sector, especially small and medium-sized enterprises increased the volume of committing supply to public sector consumption (Figure 2 and Figure 3). 
Figure 2. Public procurement from private sector in 2012-2015, billion UZS

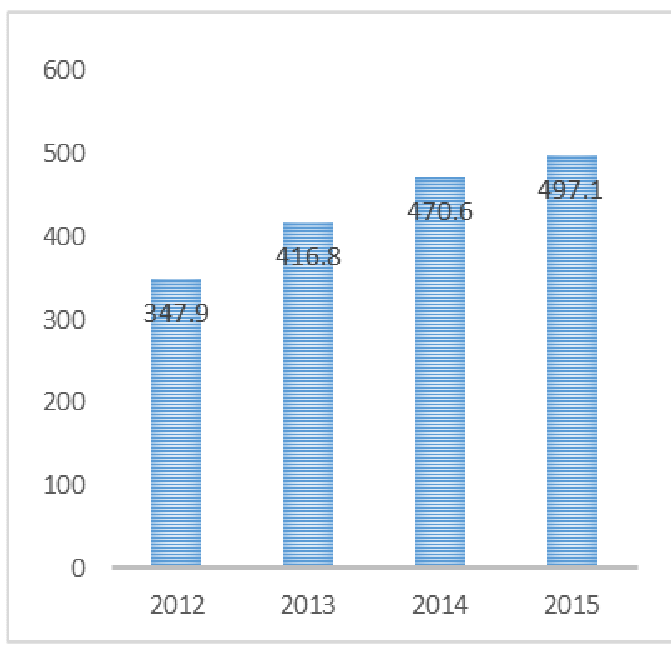

Source: UZEX, 2016
Figure 3. Number of private sector suppliers for public needs in 2011-2015

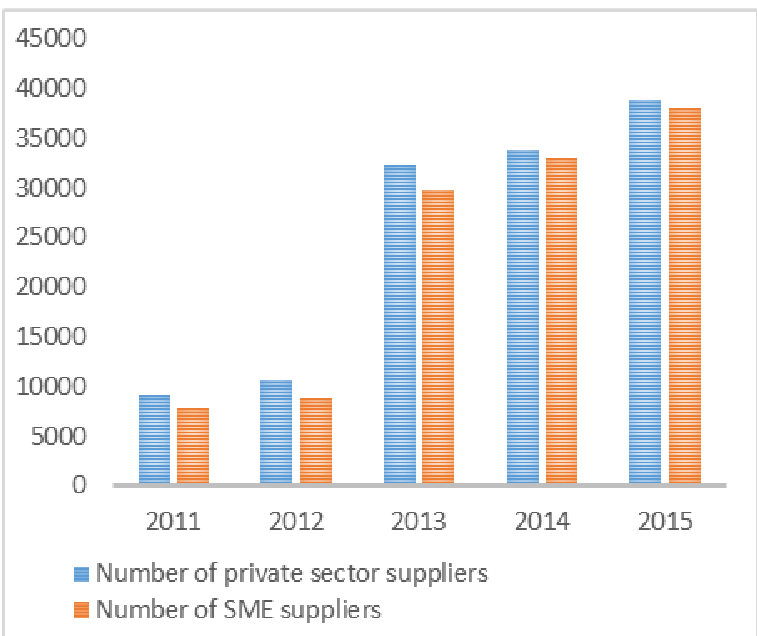

Source: UZEX, 2016

Interests of public and private sectors coincides in infrastructure and utilities in Uzbekistan. Many large construction projects and infrastructure building are implemented by private firms. Participation of both parties is enabling to ensure open market access and fair competition, to protect the public interest and to maximize value added.

\section{Conclusion and Recommendations}

A long experience of private sector involvement in meeting the public needs exist with a growing acceptance that private sector linkages serve as an additional and complementary instrument to supply of infrastructure and services. However, there are no any standardized and globally accepted schemes of public and private sector relations which fit to all economies. As emphasized above, governments choose the level and coverage of private sector engagement in consistent with economic profile, fiscal condition and business environment. Developing and transition economies are in different path because of ongoing development process and unavailability of particular services and goods by private sector, especially in public procurement and construction. Limited case for standard public and private sector relations allows to propose following core recommendations deriving from the key objectives proposed by OECD experts:

1. Parties should reduce long term cost and should check that supplier is able to manage it in a most cost effective manner

2. Public sector should provide incentives to the contractor to deliver projects on time, to required standard and within the budget;

3. Private sector should improve the quality of service and increase revenue through more efficient operation

4. Public and private sectors should run a consistent and predictable profile of expenditure and profit, effectiveness and relevance.

\section{References}

1. Jasiukevicius, L. and Vasiliauskaite, A. (2013). The Relation between Economic Growth and Public-Private Partnership Market Development in the Countries of the European Union. Journal of Economics and Management. 18 (2).

2. Ke et al. (2010). Preferred risk allocation in China's public-private partnership projects. International Journal of Project Management. No.28.

3. Sharma, M. and Bindal, A. (2013). Public-Private Partnership. International Journal of Research. Vol.1. No.7.

4. Samii et al. (2002). An Innovative Public-Private Partnership: New Approach to Development. World Development. Vol.30, No.6.

5. IMF, Fiscal Affairs Department.(2004). Public-Private Partnerships.

6. ADB Institute. (2015). Engaging the Private Sector in Public-Private Partnerships. Policy Brief. No.4.

7. Akitoby, B., Hemming, R. and Schwarz, G. (2007). Public Investment and Public-Private Partnerships. IMF Economic Issues. No.40. 